Cahiers $d u$ MONDE RUSSE

\section{Cahiers du monde russe}

Russie - Empire russe - Union soviétique et États indépendants

$45 / 1-2$ | 2004

Stratégies impériales

\title{
Iz istorii zemleustrojstva evreev v SSSR
}

Dina A. AMANŽOLOVA

\section{OpenEdition \\ Journals}

Édition électronique

URL : https://journals.openedition.org/monderusse/8683

DOI : $10.4000 /$ monderusse. 8683

ISSN : $1777-5388$

Éditeur

Éditions de l'EHESS

Édition imprimée

Date de publication : 1 janvier 2004

Pagination : 209-240

ISBN : 2-7132-2008-4

ISSN : $1252-6576$

Référence électronique

Dina A. AMANŽOLOVA, «Iz istorii zemleustrojstva evreev v SSSR », Cahiers du monde russe [En ligne], 45/1-2 | 2004, mis en ligne le 01 janvier 2007, consulté le 02 septembre 2022. URL : http://

journals.openedition.org/monderusse/8683 ; DOI : https://doi.org/10.4000/monderusse.8683

Tous droits réservés 


\title{
CAIR N
}

chercher : repérer : avancer

Cet article est disponible en ligne à l'adresse :

http://www.cairn.info/article.php?ID REVUE=CMR\&ID NUMPUBLIE=CMR 451\&ID ARTICLE=CMR 4510209

\section{Iz istorii zemleustrojstva evreev $v$ SSSR.}

\author{
par Dina A. AMANZOLOVA
}

\section{| Editions de l'EHESS | Cahiers du monde russe}

\section{4/1-2 - Vol 45}

ISSN 1252-6576 | ISBN 2713220084 | pages 209 à 240

\section{Pour citer cet article :}

- A. AMANZOLOVA D., Iz istorii zemleustrojstva evreev v SSSR. The Kabardians in the Russian boyar elite 1560 1700 , Cahiers du monde russe 2004/1-2, Vol 45, p. 209-240.

Distribution électronique Cairn pour les Editions de l'EHESS.

(C) Editions de l'EHESS. Tous droits réservés pour tous pays.

La reproduction ou représentation de cet article, notamment par photocopie, n'est autorisée que dans les limites des conditions générales d'utilisation du site ou, le cas échéant, des conditions générales de la licence souscrite par votre établissement. Toute autre reproduction ou représentation, en tout ou partie, sous quelque forme et de quelque manière que ce soit, est interdite sauf accord préalable et écrit de l'éditeur, en dehors des cas prévus par la législation en vigueur en France. Il est précisé que son stockage dans une base de données est également interdit. 
ДИНА А. АМАНЖОЛОВА

\title{
ИЗ ИСТОРИИ ЗЕМЛЕУСТРОЙСТВА ЕВРЕЕВ В СССР
}

\author{
Несколько общих замечаний
}

В последнее время, когда довольно долгое умолчание еврейского вопроса как составной части национальной политики и межнациональных отношений в России прекратилось, написано уже немало ${ }^{1}$. При этом вместо страдательноминорного тона, который все больше обнаруживает явную недостаточность, приобрела определенную популярность нехарактерная для отечественной историографии и культуры вообще обличительно-ироничная и снисходительная (по поводу тех или иных действующих сил и лиц истории) манера объяснения всего прошлого, не нуждающегося ни в разоблачении, ни в оправдании. Знание истории объективно необходимо нам самим. Но нередко еe интерпретация выглядит как попытка оправдания нынешних жизнеустройства и поведения, будто бы заведомо обреченных на бо́льшие в сравнении с минувшим справедливость, нравственность и совершенство.

Нетрудно заметить, что в публикациях о еврейском вопросе в России доминирует признание действительно сильной или даже исключительной

\footnotetext{
1. См., например: Ф. Кандель, Очерки времен и событий. Из истории российских евреев, М., 1994; Г. В. Костырченко, В плену у красного фараона, М., 1994; Его же, «Депортация - мистификация (Прощание с мифом сталинской эпохи)», Отечественная история, 1, 2003; А. Д. Степанский, «Большевизм и русское еврейство», Вестник еврейского университета в Москве, 1 (11), 1996; В. Ю. Зорин, Д. А. Аманжолова, С. В. Кулешов, Национальный вопрос в Государственных Думах России: опыт законотворчества, М., 1999; «Из истории и мифологии революции: почему евреи? "Круглый стол”», Отечественная история, 2, 2000 и др. См. также публикации автора «Дума и этнические конфликты (1906-1917 гг.)», в: Из истории России. ХХ век. Вып. 8, М., 1997 с. 101-119; «Из истории межэтнических конфликтов в России (1905-1916 гг.)», Международный исторический журнал, 20, 2002, http://www.history.machaon.ru
} 
специфики как самого этноса, так и его судьбы, а особенно отношения к нему власти и общества. Многолетнее существование антисемитизма на уровне государственной политики и в обыденном массовом сознании в Российской империи было затем отягощено эксцессами Первой мировой и гражданской войн. После их завершения, поставив задачу достижения национального равенства и искоренения из социальной практики любых проявлений дискриминации по этническому признаку, большевики столкнулись с рядом весьма непростых проблем, решение которых не могло быть обеспечено лишь конституционным закреплением принципов новой национальной политики.

K тому же национальный вопрос (впрочем, как и многие другие) был тесно связан с экономическими, социальными, идеологическими, психологическими, культурными, международными аспектами становления советского общества и государства, а сама политика большевиков в этнонациональной сфере отнюдь не была последовательно демократической. Кроме того, политическое самоопределение поначалу не распространялось на еврейскую этническую группу и другие малочисленные народы, тогда как национально-культурная автономия априори была отвергнута В. И. Лениным еще до революции.

Ни в коей мере не отрицая весьма примечательных особенностей вопроса, в то же время отметим, что ту или иную специфику имеют каждый этнос и его история. Но есть целый ряд общих черт и принципов развития этнических общностей, национальных движений (в известном конкретноисторическом и социокультурном преломлении) и национальной политики, которые прослеживаются и при обращении к еврейскому вопросу ${ }^{2}$ В этой связи справедлив вывод Ц. Гительмана о подчиненной и ограниченной роли евсекций РКП(б), представления о значимости которых у руководства страны и лидеров самих секций сильно расходились ${ }^{3}$. Он подтверждается

2. К примеру, Ц. Гительман в 1999 г. выделил типичные образцы идентификации евреев в постсоветских Украине и России. См.: Ц. Гительман, Пристрастие, причастность, отчуждение: евреи, еврейские общины в Украине и России, Доклад на конф. «Еврейская политика и политическое лидерство в исторической перспективе». Бар-Иманский ун-т и Гарвардский ун-т, январь 1999 г., Рамат-Ган, Израиль. http://www.rjews.net/berkovich/Lvov1.htm. Они вполне походят и для характеристики адаптации других национальных групп, оказавшихся в бывших советских республиках в положении меньшинств, в т.ч. русских. См., например: С. С. Савоскул, Русские нового зарубежья: Выбор судьбы, М., 2001. В. А. Тишков справедливо указывает, что в советский период сложилась, как «негомогенное целое», устойчивая общность ценностных ориентаций, личных стратегий и даже культурного поведения людей, которая оказалась гораздо больше, чем их этнокультурная отличительность, важная лишь в той мере, какую придают ей само общество или его представители. См.: В. А. Тишков, Этнология и политика, М., 2001 , с. $161,184,196-197$. Кстати, в упомянутом докладе Гительмана как раз признается, что такая общность (не вполне корректно применительно к тому периоду обозначенная как ассимиляция) стала ведущей и для советских евреев, исключая старшее поколение, уже в 20 - 30-е гг. XX в.

3. Z. Gitelman, Jewish nationality and Soviet politics: The Jewish sections of the CPSU, 1917-1930, Princeton, NY, 1972, p. 497. 
общей историей национальных структур, созданных большевиками при Наркомнаце и партии. Все они, выполнив с точки зрения центра задачи проводников политики самоопределения наций, обеспечения политической стабильности и социально-экономического объединения сложной поликультурной среды, были практически одновременно распущены. Между тем национальные деятели во всех регионах, имевшие в большинстве своем дореволюционный политический опыт, признавшие Советскую власть, вступившие в партию под влиянием реальной силы большевиков и воодушевленные их декларациями о национальном самоопределении, имели гораздо более амбициозные планы, большей частью так и не реализованные.

Замечание исследователя советской политики в отношении евреев Г. В. Костырченко о небезукоризненности трудов Гительмана и других западных ученых, не имевших ранее доступа к архивным материалам ${ }^{4}$, можно принять лишь отчасти. В работах о землеустройстве евреев ${ }^{5}$ на основе анализа опубликованных материалов и фактов (если не брать во внимание определенную эмоциональную перегруженность некоторых оценок) давалось вполне адекватное изложение событий, высказывался ряд проницательных догадок и делались серьезные умозаключения. Это, между прочим, говорит и о большом информационном потенциале советской периодики и публицистики 20 - 30-х гг. ХХ в.

4. Г. В. Костырченко, Тайная политика Сталина. Власть и антисемитизм, М., 2001 , с. 18. Кстати, его интерпретация сталинской национальной политики (с. 4042, 48-54) требует уточнений: изначально большевистская программа не предусматривала иерархию национально-государственных образований, т.к. предполагала унитарную государственность, и ни одно меньшинство за советское время не ассимилировалось и не исчезло, в т.ч. вследствие фактической реализации элементов культурной автономии. Вряд ли также можно напрямую увязывать фактическое самоопределение наций с федеративным построением партии, а ленинский федеративный проект считать безнациональным - ведь его, а не сталинскую автономизацию поддерживали националы. На деле получился симбиоз федеративной формы с унитарным содержанием при наличии различных механизмов и возможностей модернизации российских этносов как единого поликультурного социума.

5. См., например: С. Шварц, «Биробиджан», в: Книга о русском еврействе. 19171967, Нью-Йорк, 1968, с. 160-201; Ш. Абрамский, Биробиджанский проект. 1927-1959 г2., Евреи в советской России (1917-1967), Иерусалим, 1975, с. 107-125; Евреи в Крыму. Краткий очерк истории иудейских общин Крыма, научнный ред. Ю. М. Могарычев, Симферополь, 1999; Ф. Кандель, «Книга времен и событий», в: История евреев Советского Союза (1917-1939), т. 3, Иерусалим-М., 2002, c. 208-235. Последняя работа, к сожалению, не содержит ссылок на источники. 


\section{Создание КомЗЕТа: этнополитические проблемы и борьба за административный ресурс}

Фактическая история землеустройства евреев в СССР в целом реконструирована - описан общий ход событий, выявлена динамика переселения и история функционирования еврейских поселений в основных районах их обустройства - Украине, Белоруссии, Крыму, Дальнем Востоке, меньше на Северном Кавказе и в Средней Азии. Проблема еврейских местечек в западных и юго-западных областях страны, население которых после ужасов гражданской войны оказалось разоренным, лишенным возможности полноценно заниматься традиционными видами деятельности (ремесло, торговля, кустарный промысел и пр.) в силу их «непролетарского» характера, стала особенно острой в 20-е годы. В пределах бывшей черты оседлости к тому же наблюдался земельный дефицит, и переход к сельскохозяйственному труду был осложнен. Однако руководство страны считало необходимым провести классовую линию в отношении еврейских масс, сделав их частью «подлинно трудового» народа - рабочих и крестьян. Зарубежные авторы сходятся во мнении, что масштабные мероприятия Советской власти, предпринятые главным образом на средства иностранных еврейских организаций, если и решили социально-экономические проблемы еврейской местечковой бедноты, все-таки не были удовлетворительными с точки зрения полноценного обеспечения этнокультурных и, уж конечно, политических интересов и потребностей евреев ${ }^{6}$.

Впрочем, как и в отношении других меньшинств, решение еврейского вопроса определялось основополагающей классовой парадигмой большевизма. А потому землеустройство, проводившееся на многих окраинах СССР как составная часть аграрной и национальной политики, предусматривало в первую очередь радикальное изменение экономической базы жизнедеятельности этнических общностей и создание из них социальной основы нового государства в лице рабочих и крестьян, в связи с чем в 1924 г. был создан Комитет по землеустройству трудящихся евреев при Совете Национальностей ЦИК СССР и ВЦИКе (КомЗЕТ).

6. С. Шварц, в частности, утверждает, что полупринудительная колонизация Биробиджана проводилась не во имя разрешения проблемы еврейской нужды и тем более не для разрешения еврейской национальной проблемы, а для заселения пограничных областей в интересах внешней безопасности. См.: С. Шварц, Указ. соч., с. 176. С ним соглашается и Ш. Абрамский, который считает, что в своей речи «О проекте Конституции СССР» в конце 1936 г. И. В. Сталин по существу признал банкротство Биробиджанского проекта с точки зрения условий преобразования автономных областей в советские республики. См.: Ш. Абрамский, Указ. соч., с. 119-120. Правда, он не оговаривает, что нет никаких доказательств решимости Сталина провести такое преобразование именно Еврейской автономной области (далее ЕАО). Кстати, и в 90-е гг. не произошло доогосударствление ЕАО, в отличие от всех других АО бывшей РСФСР, также в большинстве не имевших численный перевес титульного этноса. 
Если эта задача в целом была решена, то собственно национальная политика предусматривала, прежде всего, политическое решение вопроса, и здесь космополитическая программа большевиков входила в противоречие с их заявками. Это обусловило и противоречивую практику национального самоопределения в СССР, в т.ч. меньшинств, в конечном счете, сделав ее заложниками и центр, и национальных деятелей. Не случайно на совещании Агитпропа ЦК ВКП(б) по борьбе с антисемитизмом 26 августа 1926 г. руководитель Общества по землеустройству трудящихся евреев в СССР (ОЗЕТ) М. А. Ларин эмоционально заявил, что главное - поднять на должную высоту отношение к национальной политике и меньшинствам, поскольку «неправильная национальная политика породила антисемитизм [...] национальные меньшинства не ограждены, наоборот, их права попираются самым наглым образом, не встречая никакой поддержки.» Как и все большевики, он уповал на политические способы решения проблемы. Предложив не выпячивать еврейские особенности, изменить социальный состав еврейского населения, более широко устраивая их на земле и создавая советы в городах с еврейским населением, а при ЦИК СССР - еврейскую секцию аналогично другим национальностям, он тут же обрушился на КомЗЕT:

[...] это организация ублюдочная, она заботится только о еврейском землеустройстве, но ей нужно также заняться и индустриализацией, она должна заботиться и о[б] административных сторонах, добиваясь, чтобы не было преследований. ${ }^{7}$

Вряд ли эта резкая оценка была справедливой. Скорее, здесь сказалась ревностная обида на очевидное умаление значимости ОЗЕТа после создания государственной структуры (к тому же вскоре Ларин был вынужден уйти с поста его главы). Да и само руководство КомЗЕТа, имевшего точно определенные права и обязанности, хорошо сознавало необходимость и сложности решения всего круга проблем еврейского населения и практически участвовало в их решении. Примечательно, что бывшие на совещании члены КомЗЕТа никак не отреагировали на выпад Ларина, а его председатель П. Г. Смидович заметил, что «люди, подверженные антисемитизму, должны исключаться из нашей советской легальности, [...] нужен моральный ожог $[\ldots]$ не только в партийной $[\ldots]$, но и в общественной среде» ${ }^{8}$. Однако в оценке ситуации преобладал классовый подход, а культурно-антропологические аспекты оставались на заднем плане или вообще не замечались.

Главная идея последней и наиболее основательно анализирующей интересующие нас вопросы работы Г. В. Костырченко состоит в наличии

7. РГАСПИ, ф. 17 , оп. 60 , д. 832 , л. $31,33$.

8. Там же, л. 37-38. О кампании 1926-1929 гг. по борьбе с антисемитизмом см.: Г. В Костырченко, Тайная политика Сталина, Указ. соч., с. 100-111. 
государственного характера негласного антисемитизма в сталинской политике 9 . Но она не исключала, тем не менее, реальных мер, в т.ч. пропагандистских, имевших подчас самодовлеющее значение, по решению еврейских национальных проблем, кстати, как и в отношении других народов. Этот историк на основе большого числа архивных материалов, главным образом партийного происхождения, проделал внушительную работу по реконструкции и анализу антисемитской «тайной политики Сталина», укладывающейся все же в общий подход большевиков к национальным проблемам. В контексте избранной версии автор рассматривает и историю землеустройства евреев, обобщая ход и основные итоги работы партийных, государственных и общественных структур, в т.ч. КомЗЕТа, как трансляторов генеральной линии партии-государства. Относительно конкретной роли евсекций партии в землеустройстве евреев, очевидно, наиболее предметно высказался Гительман, признав их усилия в целом положительными. Что же касается КомЗЕТа, его значение изучено вряд ли достаточно. Многочисленные материалы фонда Комитета, да и другие источники, все еще не полно введены в научный оборот. Между тем они дают возможность уточнить и выяснить ряд немаловажных вопросов и деталей.

В частности, это касается нюансов образования и работы Комитета, в ходе которого вопросы о землеустройстве и автономии евреев оказались тесно переплетены. Уже в мае 1919 г. Оргбюро ЦК РКП(б) по докладу комиссара по еврейским национальным делам С. М. Диманштейна признало желательным привлечение еврейских масс Западного края к земледелию и борьбу с антисемитизмом, выделив для этого «известную сумму» ЦБ евсекций. При подготовке вопроса использовались данные будущего члена КомЗЕТа инженера-агронома Ю. В. Гольде. Коллегия Наркомзема 12 июля не вполне вразумительно указала: «организация еврейских сельскохозяйственных коммун и кооперативов» на свободных фондах «не должна иметь специфического свойства». С 1922 г. для создания этих коммун и кооперативов стали активно привлекаться средства иностранных организаций - OРТ, ЕКО, Джойнт ${ }^{10}$.

В ноябре 1923 г. замнаркомнаца Г. И. Бройдо представил в Политбюро ЦК РКП(б) записку об образовании при ЦИК СССР комитета по

9. Г. В. Костырченко, Указ. соч., с. 19, 116.

10. РГАСПИ, ф. 445, оп. 1, д. 19, л. 1, 2-4, 5; Г. В. Костырченко, Указ. соч., с. 89-91. ОРТ - Общество ремесленного и земледельческого труда среди евреев в России, создано в 1880 г., после I мировой войны приобрело международный характер, центр в Берлине. ЕКО - Еврейское колонизационное общество, основано в 1891 г. в Лондоне. Джойнт - американская благотворительная организация, создана в 1914 г. в США для оказания помощи пострадавшим от войны евреям, в Советской России в 1921 г. работала в рамках проекта АРА, возглавлявшегося министром торговли США Г. Гувером. Весной - летом 1923 г. деятельность АРА была прекращена по политическим мотивам, однако работа Джойнта, выделявшего значительные средства на землеустройство евреев, несмотря на противодействие ЦБ евсекций, продолжалась. См.: РГАСПИ, ф. 17, оп. 84, д. 565, л. 5, 7, 9об, 35. 
землеустройству евреев, которую Костырченко рассматривает как официальную инициативу еврейской колонизации юга Украины и Северного Крыма. Кроме того, журналист и заведующий Всероссийской сельскохозяйственной и кустарно-промышленной выставкой А. И. Брагин в своей записке обосновал адрес мероприятия - Северный Крым, степи Украины и Черноморское побережье до границ Абхазии. Он напоминал: Советская власть однажды сделала попытку разрешить политическую сторону проблемы проектом Еврейской Белорусской Республики, который «не был реализован, очевидно, потому, что, разрешая национальнополитическую проблему еврейских трудовых масс, он не разрешал проблему социально-экономическую». Комбинированное решение обеих проблем виделось путем создания в СССР специального района еврейского земледелия. В течение 4 лет, к 10-летию Советской власти, - с пафосом продолжал автор, - доказав свою жизнеспособность, земледельческие колонии, смогут быть выделены как особая еврейская автономная область. Брагин также предлагал создать специальный комитет во главе с одним из наиболее авторитетных в СССР и за границей деятелей и считал, что максимально широкая государственная постановка вопроса непременно привлечет интерес и сочувствие всех экономически и политически мощных еврейских организаций в Америке и Европе ${ }^{11}$.

ЦБ евсекций не высказалось тогда о самоопределении евреев в Крыму. Гораздо важнее считался, очевидно, организационно-кадровый вопрос Бюро предложило включить в состав будущего органа компетентных в еврейской работе товарищей, а позже (в лице М. Я. Фрумкиной и Г. Л. Пятакова) настаивало на обеспечении за евреями от трети до половины его членов. В то же время Бюро не согласилось с «преувеличенными надеждами на приток огромных средств из-за границы». Еще в 1920 г. ЦБ евсекций рьяно отстаивало необходимость ужесточения коммунистического контроля над заграничными обществами помощи евреям, их раскола и лишь с включением его членов в КомЗЕТ в реальной работе смягчило свою позицию. Однако уже тогда ЦБ рассчитывало на будущую «автономизацию» евреев и просило Политбюро ЦК РКП(б) «по политическим внутренним и международным соображениям» выдвинуть на съезд представителей губотделов нацменьшинств и автономных республик представителей еврейского населения с правом решающего голоса «так же, как автономные республики.» $^{12}$

11. Г. В. Костырченко, Указ. соч., с. 91-92; РГАСПИ, ф. 445, оп. 1, д. 19, л. 13-14.

12. Там же, л. 10, 16, 22. В 1922 г. член бюро А. И. Чемерисский подчеркивал также внешнеполитическую значимость вопроса, поскольку еврейская буржуазия «толкует об антисемитизме советской власти, не допускающей не только национального самоопределения евреев, но и самоопределения еврейских трудящихся масс» (видимо, он имел в виду отвергнутую Лениным сталинскую идею самоопределения трудящихся каждой национальности). Там же, Д. 50, л. 32об-33, 256. Судя по всему, ставить прямо вопрос о политическом самоопределении евреев ЦБ евсекций не решалось. 
Не затрагивал вопрос об автономии и директор русского отдела и заведующий агрономическим отделом Джойнта Ж. Розен. В интервью Еврейскому телеграфному агентству (ЕTA) в январе 1924 г. он привел прагматические аргументы в пользу проекта: переселение в Крым будет лучшим исходом, поскольку затраты на одну еврейскую семью, с учетом строительства жилья, транспорта и пр., составят не более 500 долл., тогда как во всех других странах они достигают не менее 5000 долл. К тому же, говорил Розен, крымские колонии не помешают развитию Палестины, и впоследствии из них возможно переселение на Ближний Восток, а сам план может быть торжеством экономического и политического значения, спасением евреев от вымирания и их возрождением. Кстати, Розен, возглавив созданную летом 1924 г. Американскую еврейскую агрономическую корпорацию Агро-Джойнт, довольно быстро завоевал уважение и симпатии в КомЗЕТе. В интервью ЕТА в сентябре 1925 г. П. Г. Смидович подчеркнул его «исключительные персональные заслуги», «недюжинную дальновидность, отзывчивость, компетентность и преданность идее колонизации еврейских масс». В мае 1926 г. член КомЗЕТа А. И. Вайнштейн также заявил заграничной делегации Агро-Джойнта, что Розен «сжился и стал близким и дорогим со всеми руководителями дела землеустройства трудящихся евреев» ${ }^{13}$.

Итак, 8 февраля комиссия Политбюро ЦК РКП(б) под председателем А. Д. Цюрупы одобрила создание КомзЕТа, предложив включить в него председателем П. Г. Смидовича - заместителя председателя ВЦИК и ЦИК $\mathrm{CCCP}^{14}$, его заместителем Х. Г. Раковского, членами - наркома земледелия Украины И. Е. Клименко, С.-Г. Саид-Галиева и Г. И. Бройдо от Наркомнаца, наркома земледелия РСФСР А. П. Смирнова, представителя ЦБ евсекций М. Я. Фрумкину, представителей от ЦК КП(б) Белоруссии и Украины. Наряду с особым мнением Фрумкиной и Пятакова по составу, вообще против создания Комитета был Смирнов. Он руководствовался общегосударственными политическими соображениями и экономической целесообразностью. Исходя из общего состояния аграрного сектора, нарком указывал, что евреи составляют ничтожный процент от нуждающихся в переселении крестьян, а само переселение прекращено из-за отсутствия всяких ресурсов. Смирнов предлагал устраивать евреев на свободных землях РСФСР и Украины на общих основаниях и с расчетом, «чтобы осевшее еврейское население было предохранено от соблазна увлечения торговлей». А поскольку есть надежда

13. Там же, л. 21 и об.; ГА РФ, ф. 7541 , оп. 1 , д. 110 , л. 37 ; д. 100, л. 8.

14. Потомственный дворянин Тульской губернии Петр Гермогенович Смидович (1874-1935) имел польско-русские корни и входил в старую гвардию московских большевиков. Его кандидатура оказалась наиболее приемлемой: не входя в высшее партийное руководство, он занимал второе место в формальной иерархии советской бюрократии, являясь заместителем М. И. Калинина, озвучившего и признавшего авторство идеи еврейской автономии. $\mathrm{K}$ тому же Смидович уже имел дело с этноконфессиональными проблемами, возглавляя Комитет содействия народам Севера и Секретариат, а затем Комиссию по делам культов во ВЦИКе. 
на привлечение постороннего капитала, можно ограничиться созданием еврейского комитета из заинтересованных частных обществ и лиц. Выпячивание вопроса к тому же «было бы на руку антисемитам», и изъятие огромного фонда, особенно на Украине, из-за скудности государственных средств на помощь земледельцам вызовет обострение национальнополитической вражды. Вдобавок, отмечал он, у евреев нет земледельческих навыков, что делает предприятие грандиозного масштаба рискованным, когда существующие еврейские колонии не дают оснований для оптимизма, а точные размеры действительного тяготения городских масс евреев к земледелию не выяснены. Смирнов был также категорически против образования особой ЕАО как искусственной «на чужой территории, из пришлых со стороны элементов», чем она будет резко отличаться от сложившейся практики образования автономий, «которые основываются на началах естественного самоопределения национальностей, совместная жизнь и быт которых на занимаемой ими территории сложились исторически.» ${ }^{15}$

24 апреля 1924 г. Политбюро ЦК РКП(б) утвердило и дополнило решение комиссии, однако окончательно состав и полномочия КомЗЕТа были определены позже, а пока он работал в качестве комиссии Политбюро. Очевидно, это было связано с протестами как Смирнова, так и украинского руководства. На заседании 2 июня КомЗЕТ констатировал, что, несмотря на двукратное предложение Смидовича в ЦК КП(б)У выделить представителя согласно постановлению Политбюро, этого не сделано, «и мотивы не доведены до сведения Комитета». Здесь же было решено, что состав Комитета определяет ЦИК СССР, с обязательным включением в него представителей СНК союзных республик. Председателем Комитета выдвигался П. Г. Смидович, его заместителем - М. В. Фрунзе. В состав предлагалось включить А. П. Смирнова, И. Е. Клименко, У. Ибрагимова, М. И. Фрумкина; А. Н. Мережина и А. И. Чемерисского от ЦБ евсекций, председателя ЦК ОРТа Ю. В. Гольде, С. Диманштейна, представителя Белбюро ЦК РКП(б) Левина и Угарова. ЦК КП(б)У принципиально отказался направить своего представителя в Комитет, и Смидович предлагал пригласить его на обсуждение вопроса в Политбюро.

Резкое противодействие ответработников Украины подтвердили выступления секретаря ЦК КП(б)У Э. И. Квиринга и наркома юстиции Н. А. Скрыпника на VIII Всеукраинской партконференции в мае 1924 г. против специального сосредоточения евреев в одно место. В отчете ЦБ евсекций указывалось позже:

Убедившись в неизменности постановления Политбюро, украинские товарищи сделали все возможное для затягивания выделения земоргана и даже в первый раз за время существования советской власти позволили себе 
установить различие в земельной норме по национальному признаку, которое с большим трудом удалось отменить.

Окончательное решение Политбюро приняло 14 июля 1924 г. На КомЗЕТ возлагалась обязанность определить районы землеустроения, прежде всего, организовать поселение еврейских масс на юге Украины и в Северном Крыму, где имелись свободные площади и уже были организованы еврейские колонии. Ставилась задача всячески поощрять коллективные формы землепользования и землеустройства, что вписывалось в общий курс партии на уничтожение частной собственности и обобществление сельского хозяйства. Комитету предоставлялось «право ведения переговоров с иностранными организациями и учреждениями на предмет привлечения средств для осуществления поставленной задачи».

Президиум ЦИК СССР 29 августа 1924 г. утвердил измененный состав КомЗЕТа. Заместителем Смидовича стал член ЦК РКП(б), нарком земледелия РСФСР А.П. Смирнов, в Комитет вошли замнаркома иностранных дел М. М. Литвинов, полпред и торгпред в Великобритании Л. Б. Красин, А. Л. Шейнман (в 1925 г. нарком внутренней торговли, с 1926 г. зам. наркома финансов), нарком земледелия Украины Клименко, а также В. М. Игнатовский, С. М. Тер-Габриэлян, глава ОЗЕТ Ларин, председатель ЦК профсоюза сельхозрабочих Н. М. Анцелович, Мережин, Диманштейн, Гольде, У. Ибрагимов. Комитет одновременно работал при ВЦИКе $\mathrm{K}^{16}$.

Положение о КомЗЕТе было утверждено 25 октября 1924 г.: основными задачами являлись определение районов вселения и земельных участков из

16. В решении Политбюро среди членов КомЗЕТа указывались также представители ЦБ евсекций А. И. Чемерисский и А. И. Вайнштейн - член коллегии Наркомфина СССР, начальник финансового контрольного управления, зам. наркома внешней торговли РСФСР М. И. Фрумкин. В 1925-1927 гг. в КомЗЕТ входили, кроме председателя Смидовича, Ларин, М. И. Лацис, Мережин и Вайнштейн, ответственный секретарь И. В. Теумин. При президиумах ЦИКов Украины, Белоруссии, Крыма и Молдавии, а также Гомельском, Смоленском, Брянском, Псковском и других губисполкомах (гиках), где намечалось вселение, создавались соответствующие комиссии. Так, в 1925-1927 гг. они работали также при Президиуме ЦИК Дагестана, в Курской области, Северо-Кавказском крае и Великолуцком округе. РГАСПИ, ф. 151, оп. 1, д. 43, л. 1-2, 7; ф. 17, оп. 163, д. 437 , л. 24 и об; ф. 445 , оп. 1., д. 19, л. 78, 84-85; д. 96, л. 78-79; ГА РФ, ф. 3260, оп. 5, д. 57 , л. 13,9 и об; ф. 7541 , оп. 1, д. 153, л. 3. ЦБ евсекций и украинское руководство конфликтовали не раз. В 1923 г. Оргбюро ЦК КП(б)У обратило внимание ЦК РКП(б) на то, что ответработники ЦБ евсекций «в отношении еврейской работы проявляют некоторые националистические уклоны», а ЦК КПУ своими решениями ограничивало организационные возможности расширения культурной и другой работы среди еврейского населения. В свою очередь, ЦБ евсекций обвиняло украинских деятелей в попустительстве подрывной антисоветской деятельности Джойнта и других иностранных обществ, и Всеукраинское совещание евсекций высказалось за усиление партийной и советской работы в еврейских колониях, т.к. «успешная работа национальных организаций помощи [...] неминуемо создает у колонистов представление, что о них заботится не столько Советская власть, сколько еврейство». Там же, ф. 445, оп. 1 , д. 153 , л. $22,34,48$. 
свободных площадей государственного фонда совместно с соответствующими органами, содействие организации переселения и обустройства трудящихся евреев с применением установленных для переселенцев и расселенцев льгот, а также обеспечение хозяйственного развития новоселов ${ }^{17}$. На деле КомЗЕТу пришлось заниматься не только проблемами землеустройства, но и социальными, политическими, культурными и иными вопросами.

Между тем украинские деятели продолжали отстаивать свою позицию и, судя по всему, считали нужным предоставить землеустройство евреев не всесоюзному органу, а республике. В декабре 1924 г. Политбюро, рассматривая украинские вопросы по докладу Квиринга и Чубаря, в т. ч. приняло решение по поводу идеи создать еврейский переселенческий комитет при УкрЦИКе. Признавалось необходимым сохранить КомЗЕТ при ЦИК СССР, а ЦК КП(б)У предложено «вместо самостоятельного еврейского переселенческого комитета на Украине организовать соответствующую секцию Комитета, существующего при ЦИКе СССР, с тем, чтобы прежние директивы о принятии всех мер к наделению евреев землей были оставлены в силе.» Однако вскоре республика добилась своего: в январе 1925 г. Политбюро приняло предложение ЦК КП(б)У (Квиринг) создать не секцию КомЗЕТа, а еврейскую секцию при переселенческом комитете Всеукраинского ЦИКа ${ }^{18}$, что повышало самостоятельность Украины в аграрной и этнополитической сферах.

\section{Организация землеустройства: «хозяйствующие субъекты» и финансовые вливания}

По переписи 1926 г. в СССР насчитывалось 2562100 евреев, в том числе в России - $21 \%$, на Украине - $61 \%$, в Белоруссии - $16 \%$ от общего числа. Поначалу деятельность КомЗЕТа была нацелена на землеустройство евреев в названных регионах и местах их традиционного проживания. На сплошных свободных участках создавались поселения, изначально ориентированные на коллективное хозяйствование. В 1926 г. КомЗЕТ провел регистрацию менее $50 \%$ желающих заняться сельским хозяйством, в основном из бывшей черты оседлости, одновременно продолжая переселение. За 1925 - 1927 гг. только из Украины на новые места выехали 11577 семей, из России - 1452 . Всего для 14170 семей было отведено 325133 га свободных земель ${ }^{19}$. Работа эта

17. ГА РФ, ф. 3316, оп. 21, д. 105 , л. 24.

18. РГАСПИ, ф. 17, оп. 163 , д. 467 , л. 23-24; д. 470 , л. 51.

19. ГА РФ, ф. 3316, оп. 21, д. 105, л. 28-30; ф. 7541 , оп. 1, д. 153 , л. 15 . Из 123738 зарегистрированных было 5490 земледельцев, 8496 кустарей, 3725 рабочих, 2068 служащих, 929 извозчиков, нетрудовых: лиц свободных профессий 635, торговцев 4 858, лиц неопределенной профессии 11778. 
чаще всего проводилась без поддержки или даже в условиях противодействия органов власти на местах, достаточно скромным штатом Комитета.

Так, наркоматы земледелия РСФСР и УССР в 1924 г. выделили для этих целей 80 тыс. десятин земли, в том числе 50 тыс. в Крыму. Однако аграрная перенаселенность ряда районов Украины, необходимость отвлечения финансовых, материальных и иных ресурсов, организационных усилий для устройства евреев раздражали руководство республики. ВУЦИК предлагал активизировать переселение евреев на восток страны, ссылаясь на факты межнациональной напряженности среди сельского населения республики. Помощь со стороны иностранных организаций, налоговые льготы для обустройства еврейских хозяйств порождали непонимание и недовольство украинских земледельцев-переселенцев, которые не получали такой поддержки. Массовый характер приобрели бандитизм, угон лошадей у переселившихся евреев. Член коллегии Наркомзема республики М. Вольф приводил следующий пример: в Ново-Полтавской сельскохозяйственной школе для евреев-переселенцев сосредоточено 500 голов отборного скота, в то время как в южных областях Украины крестьяне вынуждены продавать коров за 30-40 рублей. В письме в КомЗЕТ он предлагал больше доверять местным работникам, чтобы избежать осложнений на селе, особенно в правобережной Украине ${ }^{20}$.

В самом деле, отношение крестьянства к еврейскому землеустройству было далеко неоднозначным. Большинство выступало за равные условия наделения землей и обустройства, хотя Агро-Джойнт старался помогать и соседним с еврейскими колониями инонациональным селениям. Да и этнополитическая элита автономий всячески стремилась отстоять свою экономическую и политическую самостоятельность перед центром. Совещание наркомов земледелия автономных республик при Федеральном Комитете по земельному делу при Президиуме ВЦИК в ноябре 1926 г. постановило:

Признать, что впредь до окончания сплошного землеустройства в автономных республиках вопрос о переселении в эти республики извне оставить открытым, предоставив наркомземам самостоятельно намечать районы, могущие быть заселенными до окончания сплошного землеустройства. ${ }^{21}$

20. РГАСПИ, ф. 151, оп. 1, д. 43, л. 26-31. Существенные проблемы возникли у КомЗЕТа и при организации переселения в Крым, поскольку его руководство в лице председателя ЦИК республики В. Ибраимова довольно упорно сопротивлялось выделению земель, ссылаясь на необходимость землеустройства крымских татар и отсутствие свободных фондов. См. подробнее: РГАСПИ, ф. 17, оп. 85, д. 109, л. 3-4, 9-10, 12-15; ГА РФ, ф. 3260, оп. 6, д. 45, л. 25, 28, 37-40, 55-62, 67; оп. 5, д. 57, л. 20, 36, 64, 67; Г. В. Костырченко, Указ. соч., с. 95-97.

21. РГАСПИ, ф. 17 , оп. 60, д. 832, л. $111-120$; оп. 85, д. 135, л. 73-75; д. 134, л. 4, 6 , 169. 
Большую сложность, прежде всего по идеологическим причинам, представляло взаимодействие с заграничными организациями, активно стремившимися поддерживать еврейское население в СССР. В 1924 - 1927 гг. были заключены соглашения с Агро-Джойнт, ЕКО, ОРТом. За эти годы 68,3\% выделенных КомЗЕТу денежных средств предоставили общественные, прежде всего иностранные, организации, 20,1\% государство и $11,6 \%$ - сами переселенцы. Иностранные средства, в частности, составили 9525639 руб., госбюджетные - 2780 тыс. руб. Руководство КомЗЕТа, в т.ч. представители ЦБ евсекций, ранее весьма подозрительно относившиеся к деятельности иностранцев, всячески подчеркивали заинтересованность государства в получении средств извне, не скрывая его финансовых трудностей и особенно отмечая заслуги АгроДжойнта в еврейском землеустройстве.

Внимание к деятельности КомЗЕТа проявил в 1928 г. новый президент США Г. Гувер. В американском займе для советских евреев участвовал Дж. Рокфеллер, так же как и Гувер, приславший письма в Комитет (документы не обнаружены). Предлагая советскому правительству заем на 10 млн. долларов для оказания помощи еврейскому населению, они оговаривали его следующими условиями. При 6\% годовых Советское государство должно было начать выплату через 17 лет, выделяя в течение 10 лет по 1 млн. долларов. При этом валюта оставалась на банковском счету, тогда как еврейскому населению выдавались бы советские денежные знаки. П. Г. Смидович считал, что это соглашение невыгодно для СССР, так как содержит и другие условия. К тому же, указывал он, приходится следить за каждым шагом заграничных организаций, далеко не всегда озабоченных бескорыстными и неполитическими целями ${ }^{22}$. Впрочем, это замечание не утратило своей актуальности, учитывая жесткий прагматизм (и нередко двойные стандарты) современной внешней политики «империи по приглашению» и без оного.

Предложение комфракции КомЗЕТа об организации смешанного кредитного учреждения с участием Комитета и Агро-Джойнта Политбюро отклонило, признав после нового обращения фракции о пересмотре решения принципиальную возможность займа и создав комиссию, которая выработала его условия и формы. Они были утверждены Политбюро 26 июля 1928 г.: под гарантии Госбанка КомЗЕТ мог заключить с САСШ договор о займе в 10 млн. долл. «из 5\% годовых в течение 10 лет по 1 млн. ежегодно, начиная с 1 октября 1928 г.» Заем погашался за 10 лет частями, начиная с 1 октября 1945 г. Агро-Джойнту предоставлялся равный взносу эквивалент в советской валюте по официальному курсу, не более $25 \%$ годовой суммы могли использоваться в иностранной валюте на плановые заказы КомЗЕТа за границей. Агро-Джойнт выдавал полученные средства 
еврейским поселенцам в виде денежных и натуральных ссуд на условиях его прежних договоров с КомЗЕТом, который при этом должен был в течение 10 лет ежегодно тратить по 500000 руб. из госбюджета «для производства в районах использования займа тех безвозвратных расходов, какие при переселении [...] производятся за счет государства». На средства займа планировалось поселить около 15000 семей на вновь отведенных 100000 десятин, в основном в Крыму.

Характерно, что затем Агро-Джойнт всякий раз, когда планируемые бюджетные ассигнования КомЗЕТу сокращались, что было связано, очевидно, с острым дефицитом средств в условиях индустриальной и коллективизаторской гонки, угрожал сокращением дополнительного, сверх займа, безвозвратного финансирования, которое инициировал Розен. Руководство Комитета умело использовало этот аргумент для получения необходимых средств, вместе с тем твердо ограничивая административные расходы в смете Агро-Джойнта как непредусмотренные договором с ним ${ }^{23}$.

\section{Еврейская автономия - «дерево или гриб»? В поисках земли и людей}

К концу 1926 г. было землеустроено 50 тысяч человек, что оказалось в два раза больше, чем число евреев, переселенных сионистами в Палестину за 10 лет. Доказательством неудачи палестинского проекта была высокая стоимость выделенных 76000 дес. земли, где сионистские организации обрабатывали всего 9400 из принадлежавших им 13700 дес. $^{24}$ Да и в СССР план землеустройства евреев в 1924 - 1928 гг. осуществлялся очень медленно, главным образом из-за недостаточных бюджетных ассигнований, а также слабого привлечения еврейской бедноты в промышленность, для чего требовалось создать новые предприятия в местах ее массового проживания. КомзЕТ в лице Смидовича выступал и за обеспечение культурной автономии для евреев. Но особенно много усилий направлялось на выделение новых районов для землеустройства. Подготовив проект закрепления за КомЗЕТом Биробиджанского района на Дальнем Востоке, Смидович 24 февраля 1928 г. обратился к секретарю Президиума ЦИК СССР А. С. Енукидзе с просьбой ускорить рассмотрение вопроса в Президиуме с участием представителей Комитета, Наркомзема РСФСР и Всесоюзного переселенческого комитета. «Очень прошу. Надо», - писал он ${ }^{25}$.

Ходатайство о выделении этого района КомЗЕТ направил в переселенческий комитет еще в январе 1928 г. Утвержденная 18 июня

\footnotetext{
23. РГАСПИ, ф. 17 , оп. 163 , д. 726 , л. 18 ; д. 735 , л. 12 ; д. 740 , л. $17-18$; ГА РФ, ф. 7541 , оп. 1 , д. 365 , л. $2,15,18-20$ и об, 25-26; 42-47.

24. Огонек, № 49, 1926, с. 5; ГА РФ, ф. 7541, оп. 1, д. 110, л. 55, 58-61.

25. ГА РФ, ф. 3316, оп. 21, д. 105, л. 297-298, 277-282; д. 173, л. 13.
} 
1926 г. Президиумом ЦИК СССР программа переселения и устройства 100 тысяч еврейских семей была выполнена к этому времени лишь на $15 \%$. На Украине было образовано 3 еврейских района, в Крыму - 2, но проблема не была решена прежде всего из-за земельного дефицита в европейской части страны. Для заселения дальневосточной окраины имелись и политические мотивы. В заключении консультанта С. Ильина по проекту КомЗЕТа говорилось, что он «и без особого постановления будет иметь в виду возможность организации автономной еврейской единицы, ибо это представляется конечной целью переселения в Бирско-Биджанский район.»

Вопрос об автономии обсуждался еще в 1926 г., когда 11 февраля по инициативе членов КомЗЕТа Мережина, Вайнштейна, Чемерисского, Ларина, Гольде была образована комиссия Политбюро ЦК ВКП(б) о землеустройстве евреев. В мае и июне вопрос откладывался, а 8 июля 1926 г. по ее предложению Политбюро постановило «держать курс на возможность организации автономной еврейской единицы при благоприятных результатах переселения.» Имелись в виду бывшие Джанкойский и Евпаторийский районы Крыма, Приазовские плавни между Кубанью и Азовским морем. Кроме того, ставилась задача изучить возможности создания массивов на Алтае, в Новороссийском и Сальском округах. Однако известно, что против еврейской автономии в Крыму было немало объективных причин и выступлений. Видимо, в связи с этим пункт об автономии был опубликован лишь 28 марта 1928 г. в постановлении Президиума ЦИК СССР уже о закреплении за КомЗЕТом Биробиджанского района ${ }^{26}$. Таким образом, формально еврейская этническая группа уравнивалась в праве на политическое самоопределение с большинством этносов страны, но местоположение будущей автономии решительно изменилось.

Немаловажную роль в задержке официального объявления об автономии, которую упоминавшиеся выше авторы не заметили, сыграло и отношение иностранных организаций. В начале 1924 г. ЕТА сообщило, что бывший председатель еврейской территориальной организации в России и на Украине А. Марголин в США и проф. Б. Д. Бруцкус в Берлине подвергли сомнению возможность еврейской автономии в Крыму, который служил «яблоком раздора между Россией и Польшей», как способной вызвать

26. Там же, д. 173, л. 23, 20, 10; Революция и нацииональности, № 5, 1935, с. 36 Название района приводится по документу. РГАСПИ, ф. 17, оп. 163, д. 576, л. 18; ГА РФ, ф. 3316, оп. 21, д. 173, л. 23, 20, 10; А. Мережин, О Биробиджане, М., 1929, с. 76-77. О дискуссиях вокруг автономии в Крыму см.: РГАСПИ, ф. 445, оп. 1, д. 82, л. 57, 61 и об; Г. В. Костырченко, Указ. соч., с. 96-99. На расширенном заседании бюро евсекций Крымского ОК ВКП(б) 9 февраля 1927 г. член ЦБ Фрумкина заявила: «Возможно, как писал И. В. Сталин, некоторые народности при Советской власти консолидируются в нацию, в т.ч. евреи, поэтому мы должны сделать все зависящее и возможное, чтобы предоставить возможность свободного развития евреям, но декларировать автономию мы теперь не можем, ибо это было бы националистическим лозунгом, наша же цель - проведение мероприятий, приближающих нас к социализму, путем перевода всех евреев на производительный труд.» РГАСПИ, ф. 445, оп. 1, д. 82, л. 149. 
противодействие украинцев и татар, а также как «очередной коммунистический блеф», глупую утопию и «способ достать за границей капитал.» По их мнению, для этого больше подходили Сибирь и Северная Россия с малочисленным населением. Вице-президент Джойнта Джемс Н. Розенберг в 1925 г. заявил о начале сбора 15 млн. долл. на колонизацию в Крыму, как одну из самых больших услуг русскому еврейству, при сочувственном отношении к работе и в Палестине, куда Джойнт направил уже около 7 млн. долл. За время его работы в России на землю осели уже 6 тыс. еврейских семей, что Розенберг считал показателем важности кампании. Он подчеркивал весьма конструктивный и успешный характер деятельности Джойнта в России. Самым горячим сторонником крымской колонизации, поскольку Советская власть в стране упрочилась, был председатель Еврейского Американского Комитета помощи Л. Маршалл. В итоге, несмотря на противодействие съезда раввинов в Нью-Йорке, еврейский конгресс в Филадельфии в сентябре 1925 г. решил собрать 15 млн. долл. и половину из них направить на еврейскую колонизацию в СССР ${ }^{27}$.

Но речь о создании еврейской автономии в СССР они не вели. Особенно показательна в этом плане беседа в КомЗЕТе 25 мая 1926 г. по итогам поездки заграничной делегации Агро-Джойнта в места землеустройства евреев. Европейский директор Джойнта А. Кан отметил, что непризнание США Советского Союза делает невозможным использование банковских кредитов для работы Джойнт, и заявил:

Это чудо, которого нет в других странах. [...] Как бы ни относились к политическому режиму в России, успех землеустройства бедных деклассированных слоев еврейского народа привлекает внимание всех слоев еврейства без различия классов и партий. Все признают величие начинания русского правительства, ибо дело переселения - великое историческое дело.

Не только этническая солидарность и взаимопомощь, но прежде всего трезвый расчет при очевидных трудностях сионистского переселения в Палестину и не имевшей аналогов государственной поддержке землеустройства в СССР с одновременным, пусть ограниченным и противоречивым, но решением других наиболее острых проблем евреев сыграли решающую роль в выделении иностранных капиталов.

Если Мережин, признав ошибочным свой пессимизм в отношении иностранных средств, привлечение которых вообще считал главным для КомзЕТа, призвал делегацию все же активнее противостоять нападкам сионистов, то Брагин, вероятно, знавший о работе комиссии Политбюро и не связанный дисциплиной, сделал акцент на создании еврейской республики или автономии: есть уже 37 автономий, почему не может быть 38. Он считал, что преступно оценивать вопрос с позиций конкуренции еврейских групп, в т.ч. сионистских, поскольку только при создании республики

27. Там же, ф. 445, оп. 1, д. 19, л. 50-51; ГА РФ, ф. 7541, оп. 1, д. 43, л. 9-12. 
«может быть речь о создании здорового и многочисленного еврейского крестьянства», и дорог каждый момент, «ибо свободная земля может уйти». Ларин же призвал американцев надавить на свое правительство для признания СССР.

Розенберг ответил довольно резко: связь вопроса о еврейской республике со страхом за судьбу всего дела землеустройства для него и Джойнта немыслима, поскольку они не привыкли «советоваться у страха». Однако он не старался обойти тему и заявил, что американское еврейство весьма и весьма заинтересовано в создании солидного базиса для землеустройства евреев, а создание республики - дело неопределенного будущего. Розенберг счел «своим долгом предупредить о чрезмерной опасности пустить телегу впереди лошади. Американское еврейство является противником создания бумажного государства.» Не пытаясь вмешиваться в чужие дела, он отметил также, что:

прежде чем говорить о республике, нужно, чтобы население прочно сидело на своей почве. Тот факт, что в России существует 37 автономных республик и областей, дает основание думать, что то же самое будет и в отношении евреев, но он считает опасным говорить об этом, пока население не пустило корней.

Заметим, что такой же аргумент содержался и в решении Политбюро. Руководитель Джойнта продолжал:

[...] широкая реклама, которая 2 года тому назад была пущена в Америке о еврейской республике, удержала ответственные американские общественные круги от оказания помощи в течение этих 2 лет, ибо нельзя давать средства на республику, которая является потемкинской деревней. Вопрос о еврейской республике должен развиваться так, как растет дерево, а не как гриб.

К мечте еврейской диаспоры о государстве, заключил он:

надо подойти с точки зрения реальной политики, и если молодые энтузиасты имеют психологическое право на такой подход к делу, то реальные политики должны к делу подойти иначе.

Тут же Розенберг адресовал вопрос об автономии А. И. Вайнштейну, который участвовал в беседе, наряду со всеми остальными инициаторами решения Политбюро об автономии. Несмотря на его принятие, он ответил уклончиво: год назад этот вопрос ответственными советскими кругами не ставился, наоборот, они были противниками идеи, т.к. для ее реализации нужны два условия, которых тогда не было - земля и люди. Теперь эта позиция не изменилась, лозунг об автономной республике они считают нецелесообразным и ненужным. Однако перспектива расселения и землеустройства на сплошных площадях в зависимости от средств и успеха привлечения еврейских масс к земледелию анализируется государством, и со 
временем при наличии реальных предпосылок правительство поставит вопрос об автономной единице. Как бы к этой перспективе ни относились другие, от нее нельзя отказываться, хотя в конкретном плане Вайнштейн согласился с Розенбергом ${ }^{28}$. Крайняя заинтересованность в получении иностранных средств и реальные проблемы в Крыму (и не только там) могут объяснить маневр с задержкой на 2 года публикации и еще более - создания автономии.

Тем временем идея переселения на Дальний Восток стала доминировать. Уже в июне 1927 г. А. П. Смирнов направил секретную записку Сталину (копии А. И. Рыкову и В. М. Молотову) о том, что на 1-м плане стоит задача заселения Дальнего Востока, ссылаясь на ее чрезвычайную остроту, по оценке военного ведомства. Оно предлагало за 5 лет перебросить 5 млн. чел. и охватить там важнейшие источники сырья, чтобы обеспечить нормальное и успешное развитие индустриализации и всего хозяйства. Торопиться заставляла, писал Смирнов, и международная обстановка, а также перенасыщенность европейской части страны и тяга крестьянства к переселению. План переселить из густонаселенных районов за 10 лет 5200 тыс. чел. военные считали недостаточным. Таким образом, работа КомЗЕТа вписывалась в общую схему социально-экономических и оборонных мер.

Несмотря на значительную удаленность района и трудности освоения, КомЗЕТ считал возможным за счет «значительной колонизационной емкости» переселить на Дальний Восток 35 - 40 тысяч хозяйств, в том числе в ближайшие 5 лет до 12 - 15 тысяч, в зависимости от размера бюджетных ассигнований и притока иностранных средств. Учитывая сложности подготовки требующихся фондов, необходимость больших инвестиций для проведения дорожного строительства, мелиоративных и других работ, Комитет предлагал закрепить за ним район на более длительный период, что могло обеспечить строгую плановость и провести расчеты на срок более 5 лет. При этом Смидович постоянно подчеркивал общегосударственный характер крупномасштабной акции, требующей содействия всех государственных органов и учреждений в освоении сельхозплощадей и создании необходимой инфраструктуры.

Территорию заселения по инициативе Комитета в феврале 1928 г. было предложено расширить на 270 - 300 тыс. гектаров за счет Приамурской низменности на запад от Хабаровска. Она представляла собой сплошную марь, совершенно незаселенную. Заболоченность, постоянные паводки, глубокое залегание грунтовых вод, жалкое состояние в основном единичных промысловых хозяйств - такие условия подвели Смидовича к выводу, что «приведение этой площади в культурное состояние требует огромных усилий и затрат.» Тем не менее, в записке в переселенческий комитет он обосновывал позицию КомЗЕТа необходимостью выполнить намеченную программу, поскольку «емкость района в прежде намеченных границах 
является недостаточной и не соответствующей программе Комитета. Задаваясь целью образовать компактно населенный национальный район», он выражал готовность «идти на все трудности, связанные с колонизацией этой территории и привлечь для этого необходимые средства», предлагая организовать здесь лесоразработки и животноводческие совхозы. Итак, 28 марта 1928 г. Президиум ЦИК и СНК СССР приняли решение о закреплении за КомЗЕТом свободных земель в приамурской полосе Дальне-Восточного края, включающей Бирско-Биджанский район, для организации сплошного заселения, за исключением площадей, занятых старожилами, казачеством, а также переселенцами, до истечения срока их устройства ${ }^{29}$.

\section{«Исполком евреев» - экономика, политика и культура}

28 декабря Президиум Совета Национальностей ЦИК СССР заслушал доклад П. Г. Смидовича о работе КомЗЕТа. Он подчеркнул чрезвычайную важность вопроса о еврейской нации, в т.ч. в политическом смысле. Большинство из 2700 тыс. евреев в пограничных районах играли такую же роль, как другие «пограничные национальности», например, Бессарабия на Украине. К концу 1928 г. усилиями Комитета к сельскохозяйственному труду было привлечено более 100 тысяч «новых трудящихся евреев». В местах их компактного проживания создавались национальные советы с использованием родного языка, учебные заведения. Глава КомЗЕТа считал одной из самых острых проблем советских евреев отсутствие у них национального представительства на местном и общегосударственном уровнях: нигде они «не находят надлежащего внимания и защиты». Более того, « [...] у евреев, - говорилось в докладе, - до сих пор нет территории, нет своей области или республики, нет своего исполкома, который приходил бы в Совет Национальностей или в другой правительственный орган и поднимал бы те или иные вопросы, организуя всесторонне жизнь национальности.» В подготовленном Смидовичем проекте постановления были пункты о выделении местечек в отдельные национальные советы, о создании предприятий в местах компактного проживания евреев и вовлечении еврейской бедноты в промышленность, но затем практически все конкретные предложения были изъяты.

Исторически сложившаяся ситуация - «нет другой нации, которая не имела бы земли» - определила и особое положение этого народа, считал Смидович. Во всех регионах, где компактно проживали евреи - Украина, Россия, Белоруссия, Дагестан и Закавказье, Средняя Азия - оно характеризовалось докладчиком как очень плохое и самое возмутительное. Даже в пролетарской республике, «как ни странно», указывал он, не исчез антисемитизм. Корни этого явления он видел в острейшей конкуренции 
ограниченных в видах хозяйственной деятельности евреев - владельцев частного капитала с представителями других национальностей, всегда воспринимавшими их как пришельцев. Аналогичная ситуация характеризовала суть армяно-азербайджанского конфликта, свидетелем которого в 1905 г. Смидович был в Баку и вместе с А. Джапаридзе участвовал в посредничестве между конфликтующими сторонами с целью их примирения. Сохранение антисемитизма в латентной форме в пролетарской среде он считал не только проявлением правого уклона, отдавая дань характерной в условиях острой внутрипартийной борьбы официальной пропагандистской риторике, а следствием более глубоких причин, прежде всего экономического влияния «верхушек», вождей на низы $^{30}$.

Вытеснение ремесленников, мелкого и крупного торгово-промышленного частного капитала за счет увеличения доли госсектора в экономике привело к серьезному ухудшению положения еврейского населения: «Теперь выбивается у них почва, в результате тысячи остаются без занятий.» В пограничных районах сотни тысяч людей оказались без легальных источников существования, не получив от революции ничего. К тому же, 2,5 тысячи местечек во время гражданской войны были полностью или частично вырезаны. «Совершенно забитая, некультурная масса, отрезанная от мира, лишенная просвещения еще в прежнее время, которая сейчас остается в том же положении», находится под сильным влиянием религии, используется контрабандистами для совершения преступлений, - указывал П. Г. Смидович. Например, в Белоруссии до $72 \%$ местечковых евреев не работали, жили на подаяния, получая 4-6 рублей в месяц, - подтвердил представитель республики его данные. Бандитизм, противодействие переселявшимся на новые земли евреям, использование антисемитских выступлений для борьбы против коммунистов под лозунгом: «Бей жидов, спасай Россию», - все эти факты внушали тревогу и подтверждали насущную необходимость продуманной всесторонней политики местных и центральных органов власти с целью их искоренения. Один из выступавших предложил дать евреям возможность самоопределиться и добиться выделения КомЗЕТу до 10 млн. рублей в год, иначе проблема не решится «до самого построения социализма.» ${ }^{31}$

30. ГА РФ, ф. 7541 , оп. 1 , д. 153 , л. 10 ; ф. 3316 , оп. 21 , д. 105 , л. $242-238$. Характерно, что все участники обсуждения вообще не упоминали о внутрипартийной борьбе, сосредоточившись на сути проблемы.

31. Там же, л. 190, 195, 198, 203-204; ф. 1235, оп. 19, д. 5, л. 42-44. Еще в апреле 1918 г. представитель объединенной еврейской партии и фракции эсеров во ВЦИК Давидович предложил принять меры к прекращению погромов в Курской губернии, Туркестане, западных и других регионах, где таким образом «выражается месть русской революции и освободительному движению, которые еврейское население приветствует.» Аналогичные предложения поступили и в СНК. В итоге тогда было решено подготовить воззвание ВЦИК о недопустимости погромов, но они были проявлением более сложной проблемы. 
Смидович считал, что КомЗЕТ не в состоянии играть роль «исполкома евреев», вынужденных обращаться в Комитет не только по земельным вопросам. Разрушение традиционных занятий - ремесел и торговли воспринималось самими евреями как постоянный, беспрерывный, тихий погром, поэтому «политическое настроение этой массы довольно плохое». Совет Национальностей, как орган представительства и реализации интересов народов страны, должен был определить организационные формы решения проблем еврейского населения страны.

В связи с подготовкой постановления о прекращении нелегальной помощи зарубежных евреев, продолжавшейся с дореволюционных времен, глава КомЗЕТа подчеркивал:

Мы прекратим эту нелегальную взаимопомощь, а что же остается: как смотреть на эту массу, которая под флагом религии продолжает оставаться темной? Это недопустимо в Советской республике [...] Мы предоставили их, как это было при царе, помощи заграничных сородичей.

Необходимо было учитывать также, что подавляющая часть расходов Комитета на аграризацию евреев покрывалась американскими пожертвованиями, тем более что переселенцы, ранее ограниченные в землепользовании, часто не имели своих средств для обустройства в новых местах, в отличие от других новоселов, а освобождение их от налогов сокращало поступления в бюджет. Для устройства хозяйства в Сибири, например, требовалось 2 тысячи рублей, - говорил Смидович, ссылаясь на данные председателя СНК СССР А. И. Рыкова. Отметим, что в апреле 1931 г. коллегия Наркомфина СССР приняла решение о стимулировании притока сбережений еврейских переселенцев из-за границы на выгодных для государства условиях. Рабочим предлагалось вносить валюту в качестве пая на жилье при обеспечении им пропорционального червонного кредита через Коммунальный банк, колхозникам в аналогичный пай долларовые взносы в колхоз не засчитывались. Все переселенцы получали «возможность приобретения на их валютные сбережения государственных займов СССР [...] с выдачей валютных сертификатов» и беспошлинно ввозить оборудование, номенклатура которого расширялась ${ }^{32}$.

В докладе Смидовича приводились интересные данные о финансировании КомЗЕТа. За 1924 - 1928 гг. из государственного бюджета поступило безвозвратно 1236 тыс. руб. и 3062 тыс. руб. возвратных, от общественных организаций соответственно - 2842 и 13823 тыс. руб. Американские и другие заграничные организации выделяли в 4 раза больше средств: из 20 млн. руб. в целом государство дало 4, 25 млн. За это время было переселено 16766 семей. На каждое хозяйство приходилось по 1350 рублей, но фактически несколько больше, так как в 1928 г. хозяйства еще лишь 
вспахали свои земли. Им могли выделяться только участки, на которые никто не претендовал, что создавало серьезные дополнительные трудности освоения новых земель. В Крыму, например, громадные средства требовались для распашки целины и добычи пресной воды на глубине до $200 \mathrm{M}$.

Не менее трудоемким и затратным было обустройство евреев на 4,5 млн. га незаселенного Биробиджанского района с суровыми бесснежными зимами, где аналогично устроенное хозяйство требовало затрат уже в 2 тыс. рублей. Из-за нехватки средств за 4 года было устроено примерно 17,5 тыс. хозяйств, то есть половина планового задания. Тем не менее, переселенческому комитету сократили смету расходов на 9 млн. руб., а для КомЗЕТа с 3 900-2 800 до 2100 тыс. руб. Смидович считал необходимым ускорить темпы переселения, добившись его удвоения - до 10 тыс. семей в год - и настаивал на специальном решении Совета Национальностей по этому поводу, с выделением средств и подготовкой всех площадей на ближайшие 5 лет $^{33}$. Переселение на Дальний Восток он рассматривал и как один из путей снятия межэтнической напряженности в ряде районов. В Дагестане, например, изгнанные евреи, говорилось в докладе, живут в гетто, и вернуть их земли мудрено: посевы на выделенных им 10 тыс. десятин травятся, а власти практически не реагируют на жалобы и обращения пострадавших. Не менее сложной была ситуация и в других районах.

К концу 1928 г. в Биробиджан переехало около 600 семей. Несмотря на тяжелейшие климатические и природные условия («нас там залило водой»), здесь постепенно расширялись посевные площади. Новоселы трудились с огромным энтузиазмом, так как понимали, что для них нет и не может быть другого источника существования и избавления от нищеты. Охотно оказывали им помощь и американские деятели, считая предпринятую кампанию наилучшим выходом из положения. В колонизации Биробиджана участвовал Северо-Американский агро-индустриальный кооператив ИКОР, который в 1930 г. организовал заем 200 тыс. долл. В докладе П. Г. Смидовича содержались предложения по регулированию государственной политики в отношении евреев, свидетельствовавшие о довольно точном знании им реального состояния дел и психологии межэтнических отношений. Так, он считал, что специальное трудоустройство евреев в промышленности через биржи труда может неблагоприятно отразиться на настроениях безработных - представителей других национальностей - и предлагал расширить разные формы переквалификации еврейских рабочих и ремесленников, открывать новые предприятия в местах их проживания и др.

Известную специфику приобрела и проблема реализации избирательных прав населения. Преимущественное занятие торговлей, применение наемного труда кустарями и ремесленниками приводило к тому, что в еврейских местечках на Украине до $40 \%$ проживающих в бывшей черте оседлости 
были лишены избирательных прав. В целом в этой республике избирательных прав были лишены 5,4\% населения, тогда как среди евреев таких было 29,1\%. В результате, говорил докладчик, лишенные всякого человеческого достоинства люди не имеют права вступать в кооперативы и «занимаются черт знает чем, лишь бы пропитаться». Наиболее голодные, забитые люди, лишенные избирательных прав, не имели и сельсоветов в своих местечках. Еще в 1926 г. КомЗЕТ инициировал решение Президиума ВЦИК о предоставлении избирательных прав еврейским переселенцам, которые ранее принадлежали «к нетрудовым категориям». Теперь Смидович предлагал внести изменения в положение о выборах и не лишать избирательных прав тех, кто получает помощь родственников, особенно изза рубежа, или общественных учреждений. Однако большинство на заседании настаивало на дополнительной проработке вопроса об избирательных правах в еврейских местечках. Глава КомЗЕТа считал также, что это единственная область национальных взаимоотношений, где продолжала расти национальная ненависть и наблюдались неоднократные вспышки конфликтов. Пресекаемые властью, они, тем не менее, могли перерасти в погромы, что требовало принятия предупредительных мер ${ }^{34}$.

По поводу реплики председателя Президиума ЦИК Грузии М. Г. Цхакая против поощрения эмиграции евреев Смидович обратил внимание на сложность ситуации и вынужденный характер разрешительной политики в отношении уезжающих в Палестину и Америку. С одной из заграничных организаций даже было заключено соглашение о помощи эмигрантам. Он подчеркнул политическое значение этого аспекта еврейского вопроса: главным аргументом в борьбе с агитацией сионистов против финансирования и организации землеустройства евреев в СССР были успехи этой работы в сравнении с сионистским движением. В итоге, говорил председатель КомЗЕТа, последний заграничный заем в 20 млн. рублей был санкционирован госсекретарем США Ф. Б. Келлогом.

34. Там же, л. 226-217, 211, 208; ф. 7541, оп. 1, д. 336, л. 11-15, 21, 26. РГАСПИ, ф. 17 , оп. 85 , д. 134 , л. 207.

Развитие антисемитизма в предшествующий период, подкрепляемое нежеланием царских властей устранить национальное неравноправие, не могло не отразиться на настроениях определенной части населения, особенно в условиях столь болезненных преобразований, резко менявших социокультурную среду, повседневную жизнь и систему ценностей. Глубокая неудовлетворенность социально-экономическим положением, противоречия политического и социального развития общества, маргинализация отдельных его групп, стереотипы поведения и восприятия еврейского населения вкупе с его фактической дискриминацией тесно переплетались и влияли на отношение к нему. Негативную реакцию на повседневные неурядицы и проблемы часто вызывали, прежде всего, казавшиеся благополучными лавочники, мелкие предприниматели, домовладельцы, арендодатели, низовой состав административного персонала предприятий, с кем простому люду приходилось постоянно контактировать и кто вдобавок зачастую имел иную этническую принадлежность. Это могло усиливать взаимное отчуждение разных социальных и национальных групп населения. 
Безвозвратные заграничные ссуды (за 4 года они составили 13823 тыс. рублей) направлялись на строительство больниц, школ, колодцев, водоснабжение и т.д., возвратные средства в 2841 тыс. рублей - на устройство отдельных хозяйств. Среди переселенцев $14 \%$ составляли земледельцы, $9 \%$ - рабочие, $22 \%$ - кустари и ремесленники. Новоселам не разрешалось использовать наемный труд, и они могли полагаться только на собственные возможности. Возвращалась на родину, а до половины уезжавших - в близлежащие города,- лишь состоятельная часть, имевшая какие-либо средства к существованию. Документы свидетельствуют, что переселенцы повсеместно сталкивались с неприятием или враждебностью не только со стороны старожилов - представителей других национальностей, но конфликтовали и между собой (польские, украинские, белорусские, переселившиеся из Аргентины, Румынии, Литвы, Германии и других стран евреи и т.д.) Напряженность вносили и конкурировавшие с партийнокомсомольско-пионерскими сионистские организации (до их запрета). K тому же среди приезжавших «не было недостатка в гастролерах, которые были не прочь за казенный счет с доплатой к литеру и на харчи в дороге покататься, немало и забубенных головушек, которым вообще терять было нечего, были и профессиональные попрошайки и в местах выхода пришедшие в конфликт с той или другой стороной уголовного кодекса». Идеалистическая молодежь и бойкие спекулянты представляли две крайности, но большинство составляла беднота, которая не имела другого выхода и дала наиболее устойчивую и трудолюбивую часть. При этом переселенцы признавались иностранным визитерам, что молятся, «чтобы Советская власть продержалась до прихода Мессии», и проявляли, по свидетельствам тех же иностранцев, полное равнодушие к преподаванию на родном языке и религии, несмотря на наличие национальных школ (и сельсоветов $)^{35}$.

\section{Прагматизм классовых противников и изнанка социалистической модернизации}

17 мая 1929 г. вопрос о мерах по улучшению экономического положения еврейских масс в СССР обсуждался на заседании Совета труда и обороны, 22 ноября было принято постановление. Ставилась задача «не выпячивать» проблему принятием специального законодательства, а пересмотреть ее решение в общих мероприятиях по организации ФЗУ, переселения, в хозяйственных планах, деятельности кооперации и др. Деятельность КомЗЕТа расширялась. В январе 1930 г. его областной орган был создан в

35. ГА РФ, ф. 3316 , оп. 21 , д. 173 , л. 304 ; ф. 1235 , оп. 44 , д. 73 , л. 244 ; ф. 7541 , оп. 1 , д. 43 , л. 3 ; д. 417 , л. 21 ; д. 418 , л. 162,172 ; д. 403 , л. $5,19,27$; д. 153 , л. 33 ; д. 221 , л. 86 ; д. 453 , л. 50 ; РГАСПИ, ф. 445 , оп. 1 , д. 82 , л. 61 и об; ф. 17 , оп. 60 , д. 832 , л. 115-116; оп. 84, д. 748, л. 108-127; ГА РФ, ф. 7541, оп. 1, д. 167, л. 6-7. 
западной области. На 1000 га из 4 еврейских колхозов было создано одно хозяйство «Гигант». Много места в работе Комитета занимала борьба с открытыми проявлениями антисемитизма ${ }^{36}$. Но центральным вопросом была подготовка образования Еврейской автономной области.

20 января 1930 г. Президиум ВЦИК заслушал доклад об обследовании Дальне-Восточного края (ДВК) и принял проект постановления СНК по этому вопросу. Была создана комиссия во главе с П. Г. Смидовичем, которой поручалось доработать проект в связи с вопросами дорожного строительства, заселения Биробиджанского района, районирования по национальному признаку и культурного строительства. Комиссия детализировала проект, и в феврале 1930 г. его приняли ВЦИК и СНК РСФСР. В решении отмечалась исключительная политическая и хозяйственная важность края. Главная задача состояла в организации его заселения, улучшении путей сообщения и связи, последовательном проведении национальной политики, особенно в смысле всесторонней помощи меньшинствам. Комиссия при этом отмечала, что пока переселенческое дело поставлено неудовлетворительно, продолжается возврат значительной части мигрантов, трудно проходит коллективизация. Трагические эксцессы коллективизации, плохое хозяйствование и культурное обслуживание в сочетании со стихийными бедствиями, неудачами в хлебозаготовках, демуниципализацией владений нередко сводили на нет усилия КомЗЕТа по хозяйственному освоению региона. Была одобрена идея учредить при Наркомземе СССР «Управление по сельскохозяйственному, кустарно-промысловому и промышленному заселению Биробиджанского района». В его подготовке должен был участвовать КомЗЕТ, чтобы с весны 1930 г. начать работу нового органа с одновременным переселением также на Камчатку и Сахалин. В июне расширенное заседание КомЗЕТа, Биро-Биджанского отряда и ОЗЕТа обсудило состояние дел и решение Дальневосточной краевой коллегии РКИ о необходимости создания с 1 октября самостоятельного Биро-Биджанского района, в августе его поддержал Наркомзем СССР, а затем правительство ${ }^{37}$.

Большое внимание положению советских евреев по-прежнему уделяли международные и особенно американские организации. В связи с коллективизацией Ж. Розен отметил в интервью нью-йоркским газетам в марте 1930 г., что при правильном ведении хозяйства коллективизация лучше, но «человеческий характер, как видно, против» нее. Агро-Джойнту «придется уступить» требованиям правительства обобществить домашний скот, хотя в колхозах все телята пали, а как только были возвращены хозяевам, опять появился приплод. Осенью 1934 г. он побывал в еврейских национальных районах Украины и Крыма и в ноябре написал Смидовичу о

36. Трибуна, № 24, 15 декабря 1929, с. 3; ГА РФ, ф. 3316, оп. 21, д. 173, л. 304; ф. 1235, оп. 44, д. 73, л. 244.

37. Там же, ф. 1235 , оп. 44, д.73, л. 233, 285-286, 288; ГА РФ, ф. 7541, оп. 1, д. 403, л. $22,55$. 
своих впечатлениях, сделав акцент на исключительно тяжелом положении и трудностях хозяйствования и условий жизни еврейского населения: отсутствие хлеба, корма для скота, топлива были типичными явлениями. На трудодень выдавалось 400 - 500 г хлеба и немного овощей, без денежной оплаты или по 10 - 50 копеек, и лишь в единичных колхозах - до 1 рубля и чуть более. Было много случаев, когда колхозников вынуждали делать взносы за трудодни в колхозную кассу из личных средств. Критическая ситуация в преддверии зимы сложилась с обувью, одеждой, топливом, фуражом и хлебом. Предоставлявшиеся властями скидки на их приобретение шли в счет недоимок на следующий год. Все это вызывало эмиграцию переселенцев. Так, из Крыма выехало 800 семей, или 20\% населения еврейских колхозов.

Розен (а благодаря исключительной энергии, деловитости и организованности руководимого им Агро-Джойнта было сделано очень много) считал, что в ходе коллективизации и переселения евреев не учитывались мобильность их хозяйств, бедность основной массы переселенцев, тяжелые климатические условия в районах обустройства, в том числе при планировании поставок продукции государству. Он выступал за предоставление льгот переселенческим еврейским колхозам, списание долгов с них и оказание им помощи. Безусловно, Смидович прекрасно знал о реальной ситуации и безуспешно пытался добиться изменения положения дел $^{38}$. Уже в 1928 г. Агро-Джойнт, а также ЕКО и ОРТ, не имевшие права на ассигнование продовольствия, пытались смягчить последствия недорода в украинских и крымских колониях. Причем руководители Агро-Джойнт и ЕКО Ж. Розен и Л. С. Зак подчеркивали невозможность иностранной помощи продовольствием и кормами, как это было в голодном 1921 г., поскольку дискредитировало бы всю работу по землеустройству евреев и остановило иностранные вливания в него. Угрозами их прекращения КомЗЕТ аргументировал свои ходатайства в вышестоящие органы о выделении государственных средств. 1 августа 1932 г. Политбюро согласилось на поставку Агро-Джойнтом вместо денежных платежей товаров ширпотреба по выбору советской стороны и приемлемым ценам при погашении их стоимости на условиях займа (5\% годовых по истечении 17 лет). Взнос общества конца 1932 - начала 1933 гг. в 450 тыс. долл. производился путем передачи средств, причитающихся Агро-Джойнту, в качестве процентов по ранее реализованным сериям займа ${ }^{39}$. Но беды евреев-

38 См. доклад П. Г. Смидовича в ЦК ВКП(б) от 13 июня 1932 г., выявленный М. И. Одинцовым в: Д. А. Аманжолова, «Горячо живу и чувствую...» Петр Гермогенович Смидович. Опыт исторического портрета, М., 1998, с. 300-307.

39. РГАСПИ, ф. 151, оп. 1, д. 43, л. 80-86; ГА РФ, ф. 7541, оп. 1, д. 133, л. 46; д. 264, л. $6-8,14-15,25,31,42-43,52 ;$ РГАСПИ, ф. 17 , оп. 163 , д. 13 , л. 49. См. также доклад П. Г. Смидовича в ЦК ВКП (б) от 13 июня 1932 г. о результатах работы комиссии партийной фракции в Президиуме ВЦИК по поводу жалоб крестьян с мест: Д. А. Аманжолова, «Горячо живу и чувствую...», Указ. соч., с. 300-307. В 1930 г. в еврейской артели им. Смидовича Калининдорфского района на Украине 
колхозников не были исключительными - все крестьянство СССР в результате безнравственного «социалистического» преобразования деревни в целях форсированной модернизации экономики страны оказалось в трагическом положении. Последствия этого сказываются до сих пор.

Между тем председатель Агро-Джойнт Розенберг в конце 1934 г. поддержал идею финансирования Биробиджана из тех средств, которые организация получала от Советского правительства в счет возврата займа, предоставленного ранее. Летом 1935 г. он намеревался приехать в СССР для ознакомления, переговоров о финансировании и размерах помощи. По свидетельству сообщавшего о встрече с Розенбергом П. А. Богданова, еврейское общество в Нью-Йорке было влиятельно и настроено по отношению к СССР недружелюбно. Гораздо большую популярность имело там сионистское движение. Поэтому инициатива Агро-Джойнта и представлявших его Розенберга, Лемана, Варбурга, Розенвальда после провозглашения 7 мая ЕАО имела важное значение ${ }^{40}$.

В одной из секретных записок конца 1934 г., направленных Смидовичу, указывались мотивы за ускорение заселения евреями, в том числе из-за границы, Биробиджанского района. Это - укрепление внешнеполитических позиций, а также крайне тяжелое положение еврейского населения Западной Украины и Западной Белоруссии, стимулировавшее его колоссальную тягу в СССР, что могло бы при поддержке советской стороны «дать советски настроенные элементы и укрепить позиции на Дальнем Востоке». К тому же разрешение заселить этот регион, в том числе эмигрантами, позволило бы с помощью прибывших из-за границы специалистов ускорить развитие автономной области ${ }^{41}$.

В связи с этим КомЗЕТу предлагалось пойти навстречу предложениям Агро-Джойнта и Агроида (польского общества). Необходимо было обеспечить отбор эмигрантов советской стороной и принятие ими советского гражданства до въезда в СССР. Кроме того, предусматривалось направление их на предприятия, отдаленные от границы на 100 - 150 км, а также допуск в Крым 50 семей и на курсы, при условии их финансирования полностью за счет Агро-Джойнта. Для начала в качестве эксперимента предлагалось переселить 300 завербованных семейств и 200 от обеих организаций с выделением каждому по 200 долл., не считая расходов на проезд до границы СССР. В дальнейшем переселенческие партии

трудодень составил 38 коп. из-за низкой производительности труда, больших площадей и найма рабсилы, на оплату которой ушло 40 тыс. руб. Из оставленной с уборки нормы хлеба, имевшего еще и низкое качество с выходом муки до 55\%, колхозникам района до половины пришлось сдать еще на дополнительные хлебозаготовки и мобилизацию семян. ГА РФ, ф. 7541, оп. 1, д. 453, л. 46-48.

40. РГАСПИ, ф. 151, оп. 1, д. 43, л. 91. П. А. Богданов в 1921-1923 гг. был председателем ВСНХ РСФСР.

41. Там же, л. 88. В статье для газеты Эмес в марте 1928 г. КомЗЕТ приводил доводы за и называл проблемы обустройства Биробиджана, касавшиеся лишь природно-географических условий. ГА РФ, ф. 7541, оп. 1, д. 237, л. 47-48. 
намеревались направлять только в ЕАО, опять же при условии их полного финансирования заграничными организациями. По секретному решению КомЗЕТа под председательством Мережина от 8 февраля 1931 г. принимались прежде всего рабочие и кустари дефицитных в Биробиджане профессий, желательно со своим инструментом и орудиями производства, которые пропускались без лицензий, а беднота лишь для организации новых или пополнения действующих колхозов и за счет иностранных организаций. Они должны были оплатить их переезд и выделить не менее 1 тыс. долл. на семью до ее выезда с их передачей через КомЗЕТ в оборотный капитал колхозов. Переселенцы, дав расписку о принятии условий переселения и труда, обслуживались наравне с другими колхозниками, а при выходе из хозяйства получали расчет на общих основаниях в советской валюте по официальному курсу. 25 мая Политбюро одобрило переселение в Биробиджанский район евреев-трудящихся из-за границы.

29 сентября 1935 г. Политбюро утвердило правила въезда из-за границы трудящихся евреев на постоянное жительство в ЕАО. Допускались «только трудящиеся - рабочие, служащие и кустари намечаемых [...] областью квалификаций, а также земледельцы, не пользующиеся наемным трудом, физически здоровые», с подтверждающими то и другое документами, преимущественно имеющие родственников или близких в ЕАО. Они должны были принять гражданство СССР и обязаться работать на указанных местах не менее 3 лет. Все расходы по подготовке поездки до советской границы несли переселенцы или помогающие им общественные организации. Багаж и инструмент провозились беспошлинно, консульский сбор не взимался, но каждый глава семьи или одиночка вносил на особый счет КомЗЕТа 200 долл., которые возвращались при отказе от переселения. На эту сумму оплачивались проезд от границы до Биробиджана (по 50-60 чел. в отдельных вагонах) и питание в пути, обслуживание до устройства на работу, расходы на домообзаводство (1 тыс. руб. на семью и 300 руб. на одиночку). Переселенцы получали дом и корову (одиночки - квартиру и по 1 корове на 5 чел.), усадебный участок ${ }^{42}$.

42. РГАСПИ, ф. 151, оп. 1, д. 31, л. 116-124, 129; ГА РФ, ф. 7541, оп. 1, д. 197, л. 6 7; РГАСПИ, ф. 17 , оп. 163 , д. 881 , л. 80; д. 1078, л. 1-4. 19 сентября 1936 г. СНК СССР передал переселение в ЕАО Переселенческому Отделу НКВД. За КомЗЕТом по договору с ним НКВД предлагал оставить выявление контингента переселенцев, организацию и укомплектование курсов по подготовке и переподготовке кадров для сельского хозяйства и промышленности, вербовку и переселение иностранцев, общее наблюдение за выполнением постановлений правительства в части устройства еврейских переселенцев в ЕАО и агитмассовую работу по всем вопросам переселения. В состав руководства республиканских, краевых и областных КомЗЕТов вводились начальники переселенческих отделов соответствующих подразделений НКВД. Переселенческие пункты Комитета в Москве и Биробиджане передавались НКВД. Однако дела не пошли лучше. В 1937 г. задолженность еврейских колхозов государству составляла 20,2 тыс. руб. на 1 хозяйство, в 1936 г. пало $33,9 \%$ поголовья скота, только 8 из 15 колхозов имели доходы для распределения по трудодням, катастрофически плохо шло поступление стройматериалов и оборудования, в итоге сорвано строительство 500 жилых домов. 


\section{Некоторые выводы}

Итак, политика учета реального баланса сил и возможностей как иностранными участниками событий, так и большевиками, определяла все перипетии истории землеустройства евреев и образования ЕАО, которая укладывалась в сталинскую концепцию национально-государственного строительства и отвечала решению определенных внешнеполитических задач. Прагматичные инициативы заграничных структур могли быть использованы только в рамках столь же прагматичных целей национальной политики. Политизация этничности, принятая за ее основу, в отношении евреев в 20-е гг. заменялась мерами по их стратификации в государстве рабочих и крестьян, где нет места ни малому, ни большому бизнесу, выражаясь современным языком. (Имперский режим, считаясь с ролью евреев в предпринимательской сфере, тем не менее, препятствовал их интеграции в российский социум, ограничивая еe правовыми, территориальными и социально-политическими рамками). Однако уже в ходе «окрестьянивания» и «орабочивания» еврейских масс оказалось необходимым и возможным предоставить им и политическую «крышу», с учетом общих внутри- и внешнеполитических обстоятельств, в т.ч. и развития сионистского движения (символически и вызывающе выглядел сам выбор местоположения автономии: Восток - но совсем не Ближний).

Важную роль в превращении КомЗЕТа в своеобразный амортизатор тяжелых последствий социалистической модернизации для евреев играл Смидович, который вскоре оказался в КомЗЕТе практически единственным неевреем $^{43}$, как подчеркивали зарубежные участники событий, внушая им уважение «своим серьезным отношением к вопросу», убежденностью в правильности и необходимости землеустройства, большой просвещенностью. Судя по изученным документам, он доверял Мережину и другим членам Комитета в решении не только текущих, но и принципиальных вопросов $^{44}$. История же землеустройства евреев не вписывается в концепцию

По признанию зам. НКВД, комдива В. В. Чернышева, переселение евреев на Дальний Восток систематически срывалось: переселено 37860 чел, из них в ЕАО осталось 18-19 тыс., остальные уехали неизвестно куда. Из оставшихся в колхозах были 2 500. Причина, конечно, виделась во вредительской деятельности областного и краевого руководства. Чернышев предложил наркому внутренних дел Н. И. Ежову временно прекратить переселение в ЕАО, провести ее очистку от антисоветских элементов, не препятствуя обратному выезду, особенно из погранполосы, где было 3 тыс. евреев, проверять каждого въезжающего «нашими органами». Такие мероприятия «будут наиболее реальными, сохраняя существование ЕАО, по очистке этой области от всего нежелательного и вредного». Ежов направил записку для сведения начальнику секретариата НКВД И. И. Шапиро с пометкой: «Мне эти мадригалы не нужны». ЦА ФСБ РФ, ф. 3, оп. 4, д. 2477, л. 168 об.; д. 2467, л. 33-34; д. 1529, л. 101-103.

43. Смидович получил шутливое прозвище «ученого еврея при губернаторе», по выражению времен Николая I.

44. 18 сентября 1924 г. Политбюро ЦК РКП(б) по докладу Мережина и Литвинова приняло решение включить в КомЗЕТ Вайнштейна, Фрумкину и Чемеринского. 
террора против наций в $\mathrm{CCCP}^{45}$ и в схему антисемитской «тайной политики Сталина». Этот сюжет из жизни евреев в СССР развивался в контексте общей драматургии социалистического строительства, а также внешнеполитических интересов страны. Как ни странно может показаться, интересы «классовых врагов» - заграничной буржуазии и большевиков ${ }^{46}$ здесь совместились и реализовались через и благодаря КомЗЕТу. В итоге социально-экономическая модернизация и культурное развитие евреев, впрочем, как и других народов СССР, проходили скачкообразно и болезненно, не совпадали ни с идеальной схемой развития и самоопределения наций, ни с проектами его приверженцев, а их последствия весьма оригинально и не менее чувствительно реализовались на постсоветском пространстве в конце XX в., а также в международных миграционных и культурных процессах.

МГУ сервиса

Кафедра культурологии

Ул. Главнал, 99

Пос. Черкизово Московской области

144022 Россия

info@mgus.ru

РГАСПИ, ф. 17, оп. 163 , д. 451, л. 27. В итоге первоначальные требования ЦБ евсекций по составу комитета были превзойдены.

Известно, что партия большевиков никогда не была союзом злонамеренных фанатиков, и Смидович - один из представителей умеренной ее части. В 1925 г., в частности, КомЗЕТ выступил за направление изъятых Помголом из синагог ценностей на кредитование евреев-земледельцев. По инициативе Смидовича - с 1924 г. главы Секретариата при Председателе ВЦИК, затем Комиссии ВЦИК по делам культов - был принят ряд решений и мер, охраняющих законодательный уровень религиозных свобод, запрещено закрытие многих православных, мусульманских, иудейских храмов, поддерживался процесс снятия ограничений в правах служителей культа и т.д. Вместе с главой отдела Наркомюста П. А. Красиковым и в начале 30-х гг. Смидович выполнял беспрецедентную правозащитную миссию в условиях самого жесткого противодействия центральных и местных властей. См.: ГА РФ, ф. 7541, оп. 1, д. 43, л. 35 об; д. 10, л. 20 об; д. 167 л. 6; Н. В. Медведев, Государство и иерковь в России (1924-1934 г2.), Канд. дисс., М., 1997; Д. А. Аманжолова, «Горячо живу и чувствую...», Указ. соч., с. 252-261. Там же приведены примеры политической толерантности Смидовича как обвинителя на заседании Мосревтрибунала по делу М. А. Спиридоновой, в ходе борьбы за власть в 1917 г. в Москве, во время Гражданской войны, изъятия церковных ценностей и коллективизации.

45. См., например: Т. Мартин, «Террор против наций в Советском Союзе», в Коммунизм, террор, человек, Киев, 2002. http://www.dwelle.de/russian/ archiv/bu23050/html

46. Заграничные организации исходили из выгодности землеустройства советских евреев, поддержанного упрочившейся Советской властью, в т.ч. для сокращения их миграции в Европу, особенно с распространением фашизма, и Америку и в связи с трудностями реализации палестинского проекта. Большевики в рамках своей социальной политики не упустили возможность использовать дополнительные средства для пропаганды преимуществ социализма и ускоренной модернизации страны. 
Архивы

ГА РФ Государственный Архив Российской Федерации

РГАСПИ Российский Государственный Архив Социально-

Политической Истории

ЦА ФСБ РФ Центральный Архив Федеральной Службы Безопасности Российской Федерации 